\title{
Administracja samorządowa i instytucje kultury w województwie podlaskim. Podstawy regionalnej polityki publicznej
}

\begin{abstract}
Streszczenie
Przedmiotem analizy w artykule jest udział administracji jednostek samorządu terytorialnego $\mathrm{w}$ prowadzeniu instytucji kultury. Na tle ogólnopolskim przeanalizowana została sytuacja w województwie podlaskim. Główne zagadnienia opracowania to zasady i metody finansowania instytucji kultury przez regionalny samorząd terytorialny oraz różne sposoby pozyskiwania przez instytucje kultury dodatkowego, pozabudżetowego dofinansowania ich działalności, szczególnie ze środków pochodzących z budżetu Ministerstwa Kultury i Dziedzictwa Narodowego oraz Unii Europejskiej.

Autor wskazuje na zróżnicowanie przestrzenne, społeczne i finansowe związane z dostępem do wydarzeń kulturalnych i uczestnictwem w nich na przykładzie województwa podlaskiego. Postuluje większą profesjonalizację zarządzania instytucjami kultury na szczeblu województwa oraz prowadzenie prorozwojowej polityki kulturalnej przez jednostki samorządu terytorialnego. Akcentuje również konieczność aktywizowania lokalnych i regionalnych społeczności w związku z wydarzeniami kulturalnymi i współuczestniczenia mieszkańców w ich organizowaniu. Uczestnictwo w kulturze na poziomie lokalnym i regionalnym oraz rozważna polityka władz w tym zakresie są podstawą budowania silnych więzi społecznych i tożsamości regionalnej mieszkańców.
\end{abstract}

Słowa kluczowe: instytucja kultury, finansowanie instytucji kultury, sektorowa polityka publiczna, regionalna polityka publiczna, współrządzenie publiczne w kulturze

\section{Local government administration and cultural institutions in the Podlaskie Voivodship. Foundations of regional public policy}

\begin{abstract}
The subject of the analysis in the article is the participation of the local government administration in running a cultural institution. The situation in the Podlaskie voivodship
\end{abstract}


has been analyzed on a nationwide basis. The main problems focus on the principles and methods of financing cultural institutions by regional self-government and various ways of obtaining additional, extra-budgetary funding for their activities, especially from Ministry of Culture and National Heritage and the European Union. The author points to spatial, social, and financial diversification related to the access to cultural events and participation in them using the example of Podlaskie voivodship. He propounds greater professionalisation related to running cultural institutions at the level of the voivodship as well as conducting pro-development cultural policy by local government units. He also stresses the need for activating local and regional communities in connection with cultural events and participation in organizing them. Participation in culture at the local and regional level and prudent government policy in this area are the foundation for building a strong social and regional identity.

Keywords: cultural institution, funding of cultural institutions, sectoral public policy, regional public policy, public governance in culture

$\mathrm{Na}$ jednostkach samorządu terytorialnego spoczywa ustawowy obowiązek prowadzenia działalności i polityki kulturalnej oraz działań związanych z ochroną dziedzictwa narodowego na podległym im terenie. Dokonuje się to przede wszystkim przez powołanie i kierowanie określonymi instytucjami kultury. Ilekroć w przepisach prawa instytucja kultury występuje bez szczegółowego określenia, należy przez to rozumieć zarówno państwową, jak i samorządową instytucję kultury. Sam sposób organizacji instytucji kultury odbywa się na podstawie aktu założycielskiego wydanego przez organizatora - Ministerstwo Kultury i Dziedzictwa Narodowego lub jednostkę samorządu terytorialnego - w którym jasno precyzuje się przedmiot działania, nazwę i siedzibę, a także określa, czy dana instytucja kultury jest instytucją artystyczną (teatry, filharmonie, opery, operetki, orkiestry symfoniczne i kameralne, zespoły pieśni i tańca oraz chóralne). Formami organizacyjnymi działalności kulturalnej, oprócz wspomnianych, są w szczególności: instytucje filmowe, kina, muzea, biblioteki, domy kultury, ogniska artystyczne, galerie sztuki oraz ośrodki badań i dokumentacji w różnych dziedzinach kultury. Może zostać utworzona instytucja kultury prowadząca działalność kulturalną w więcej niż jednej formie organizacyjnej, może również funkcjonować na zasadzie połączenia lub podziału własnej czy innej instytucji kultury.

Instytucje kultury na poziomie wojewódzkim (regionalnym) borykają się z niewystarczającym finansowaniem. Zbyt mała dotacja podmiotowa przekazywana instytucjom kultury zapewnia możliwość utrzymania obiektów i pokrycie kosztów osobowych i eksploatacyjnych, ale nie jest w stanie wspierać działań prorozwojowych. Głównym powodem takiego stanu rzeczy jest ciągły wzrost kosztów (obligatoryjnych), 
w tym składek osobowych, nałożonych przez organy państwa (np. wzrost składki ZUS), które są pokrywane z dotacji podmiotowych danej instytucji kultury. Podmioty prowadzące pomimo odpowiedniego uzasadnienia niechętnie zwiększają środki na kulturę i w związku z tym instytucje zmuszone są do ponoszenia dodatkowych kosztów w ramach własnych budżetów. W takiej sytuacji zamiast przeznaczać przychody na działalność prorozwojową, konsumują je na wydatki bieżące.

Istotnym problemem jest również profesjonalne zarządzanie (a właściwie profesjonalne współrządzenie) instytucjami kultury ze strony ich kierowników. Przejawia się to między innymi w niewłaściwie prowadzonej polityce kadrowej, co wpływa na ujemny często wynik finansowy danej placówki (koszty pracownicze najbardziej obciążają budżety instytucji kultury). Czas pracy pracowników instytucji kultury powinien być dopasowany do wykonywania konkretnych zadań, tak aby pracownik czuł się potrzebny i efektywny, a powierzone obowiązki wykonywał z przekonaniem, iż swojej „firmie” przynosi konkretne wymierne korzyści finansowe, wynikające ze świadczenia usług kulturalnych na zasadach komercyjnych lub pozyskiwania środków z innych zewnętrznych źródeł, i społeczne - poprzez realizację celów statutowych zgodnie z planem zadań, dbając jednocześnie o pozytywny wizerunek instytucji wśród odbiorców.

$\mathrm{W}$ artykule podjęto próbę analizy zasad finansowania instytucji kultury na poziomie wojewódzkim (regionalnym) na przykładzie województwa podlaskiego, jak również znalezienia odpowiedzi na pytanie o najbardziej skuteczne, efektywne społecznie i finansowo metody czy sposoby kształtowania i prowadzenia polityki kulturalnej jako jednej z sektorowych polityk publicznych na poziomie regionalnym. Dotąd dokonywane analizy najczęściej odnosiły się do poziomu centrum - do poziomu państwa i realizacji polityki publicznej na tym szczeblu. Duże nadzieje, podobnie jak inni badacze, pokładam w nowym podejściu do aktywności państwa i jego organów w prowadzeniu polityki publicznej, którą określa się mianem nowego współrządzenia publicznego (new public governance $)^{1}$.

\section{Wydatki na kulturę i dziedzictwo narodowe w województwie podlaskim na tle innych województw}

Wydatki z budżetów województw stanowią około 19 proc. wszystkich analizowanych wydatków na kulturę. Województwo podlaskie na tle innych województw

\footnotetext{
1 Za szczególnie inspirujące uznaję teksty publikowane na ten temat w „Studia z Polityki Publicznej/ Public Policy Studies".
} 
w latach 2010-2015 na kulturę i dziedzictwo narodowe wydało najwięcej środków, biorąc pod uwagę ich udział procentowy w wydatkach ogólnych. Podane w raporcie M. Modzelewskiej i T. Kukołowicza, dotyczącym finansowania kultury przez samorządy $^{2}$, wartości wynoszą od 3,94 proc. w woj. warmińsko-mazurskim w 2014 r. do 22,04 proc. w woj. podlaskim w 2010 r. Plany wydatków na kulturę w odniesieniu do wydatków ogólnych wynosiły w 2010 r. średnio 8,81 proc., w kolejnych latach systematycznie spadały, by w 2015 r. znów wzrosnąć do poziomu 7,41 proc. Wskaźnik ten przekraczał nawet 10 proc. w województwach: pomorskim, śląskim, łódzkim, wielkopolskim, małopolskim, warmińsko-mazurskim, kujawsko-pomorskim oraz podlaskim (rekord - 22 proc. w 2010 r.). Z kolei tylko w dwóch województwach średnia zaplanowanych wydatków na kulturę za lata 2010-2015 przekroczyła 10 proc. - śląskim (10,13 proc.) i podlaskim (11,04 proc.). Najgorzej wypada województwo świętokrzyskie, w którym wydatki na kulturę stanowiły średnio tylko 4,6 proc. zaplanowanego budżetu ${ }^{3}$.

Inaczej wygląda sytuacja, gdy analizujemy wydatki zrealizowane. Martwi fakt, że wskaźnik ten powoli, lecz systematycznie spada. W 2010 r. w województwach wydawano na kulturę średnio 9,10 proc. z całego budżetu, z kolei w 2014 r. już tylko 7,52 proc. Najniższy odsetek budżetu przeznacza na kulturę województwo lubuskie - w każdym analizowanym roku wskaźnik ten wynosił najmniej lub zajmował jedno $\mathrm{z}$ ostatnich miejsc $\mathrm{w}$ zestawieniu (średnia za wszystkie lata 5,24 proc.). Najlepsza sytuacja, podobnie jak w wypadku planów wydatków na kulturę, występuje w województwie podlaskim, gdzie średnia za lata 2010-2014 wyniosła aż 14,36 proc., na co bez wątpienia wpłynęła budowa Opery i Filharmonii Podlaskiej - Europejskiego Centrum Sztuki w Białymstoku (koszt inwestycji to 180,20 mln PLN) ${ }^{4}$.

W ostatnich latach poziom realizacji zaplanowanych wydatków na kulturę wzrósł. W 2014 r. średnia uzyskała najwyższą wartość - wyniosła prawie 103 proc., przekroczono zatem plan budżetowy. Jednocześnie realizacja zaplanowanych wydatków ogółem wyniosła średnio mniej - najwyżej w 2010 r. - 89,22 proc., następnie wartość ta spadała w kolejnych latach, by w 2014 r. wynieść 86,98 proc. W większości województw wykonane wydatki na kulturę zrealizowano w większym stopniu niż plany ogólnobudżetowe w niemal wszystkich latach okresu 2010-2015.

W woj. podlaskim poziom zrealizowania wydatków na kulturę jest wyraźnie wyższy niż wydatków ogółem. Prawie każdego roku na kulturę wydawano więcej niż planowano w pierwszym kwartale, pomimo kurczenia się budżetu województwa

M. Modzelewska, T. Kukołowicz, Finansowanie kultury przez samorzady. Plany, wykonania i realizacja wydatków na kulturę, NCK, Warszawa 2015.

3 Ibidem s. 4.

4 Ibidem. 
w ciągu roku. W latach 2010-2014 województwa łącznie zaoszczędziły na kulturze $381 \mathrm{mln}$ PLN (taka była różnica między planowanymi a zrealizowanymi wydatkami). Województwa, które wydały na kulturę mniej, niż zaplanowały, zaoszczędziły na kulturze około $517 \mathrm{mln}$ PLN, z kolei te województwa, które przekroczyły plany wydatków na kulturę, wydały na nią $136 \mathrm{mln}$ PLN więcej.

Analizując wydatki na kulturę, warto przyjrzeć się, jak kształtują się one na poziomie gmin województwa podlaskiego w przeliczeniu na jednego mieszkańca. Posłużą do tego badania Fundacji SocLab przeprowadzone w 2016 r. na zlecenie Wojewódzkiego Ośrodka Animacji Kultury (WOAK) w Białymstoku w ramach projektu Podlaski Pomost Kultury ${ }^{5}$. Uwzględnienie liczby mieszkańców w tym i innych wypadkach jest istotne, ponieważ podlaskie, zamieszkiwane przez niespełna 1,2 mln osób należy - obok województw opolskiego i lubuskiego - do najmniej zaludnionych regionów kraju. Po uwzględnieniu liczby mieszkańców województwo podlaskie zajmuje pod względem wydatków gmin na kulturę 12. miejsce w Polsce, z przeciętnymi wydatkami niższymi o ok. 16 zł od średniej dla całego kraju. Widać wyraźnie, że wszystkie regiony Polski wschodniej uplasowały się poniżej średniej krajowej, wynoszącej ponad $112 \mathrm{zł}$, natomiast województwo podlaskie zostało nieznacznie wyprzedzone przez lubelskie i zachowuje wyraźniejszą przewagę nad warmińsko-mazurskim, podkarpackim i świętokrzyskim.

Tabela 1. Wydatki gmin na kulturę w przeliczeniu na jednego mieszkańca według województw w 2015 r. (w PLN)

\begin{tabular}{|l|c|l|c|}
\hline \multicolumn{1}{|c|}{ Województwo } & $\begin{array}{c}\text { Wydatki gmin na kulture } \\
\text { w przeliczeniu na jednego } \\
\text { mieszkańca }\end{array}$ & Województwo & $\begin{array}{c}\text { Wydatki gmin na kulture } \\
\text { w przeliczeniu na jednego } \\
\text { mieszkańca }\end{array}$ \\
\hline Dolnośląskie & 156,21 & Wielkopolskie & 104,13 \\
\hline Mazowieckie & 130,85 & Lubelskie & 97,57 \\
\hline Zachodniopomorskie & 123,65 & tódzkie & 96,77 \\
\hline Pomorskie & 123,13 & Podlaskie & 96,01 \\
\hline Małopolskie & 116,96 & Warmińsko-mazurskie & 92,22 \\
\hline POLSKA & 112,29 & Kujawsko-pomorskie & 90,81 \\
\hline Śląskie & 110,77 & Podkarpackie & 90,53 \\
\hline Opolskie & 111,33 & Świętokrzyskie & 82,90 \\
\hline Lubuskie & 107,94 & \multicolumn{2}{|l}{} \\
\cline { 2 - 3 } & & &
\end{tabular}

Źródło: opracowanie SocLab, soclab.org.pl, dostęp: 21.06.2017 na podstawie Bank Danych Lokalnych - Główny Urząd Statystyczny, https://bdl.stat.gov.pl, dostęp: 21.06.2017.

\footnotetext{
5 Projekt realizowany w ramach Programu Bardzo Młoda Kultura Narodowego Centrum Kultury.
} 
Porównując środki gmin na inwestycje w kulturę, widzimy, że jeszcze w latach 2011-2012 podlaskie zajmowało przeciętną pozycję wśród województw, z wydatkami rzędu 42-45 PLN na jednego mieszkańca, co zbliżało się do średniej dla całego kraju, wynoszącej wówczas 43-44 PLN. W latach 2013-2014 nastąpił jednak istotny spadek nakładów na inwestycje. W $2013 \mathrm{r}$. wydatki spadły do poziomu 25 PLN (13. miejsce w kraju), w 2014 r. do 18,5 PLN (ostatnie, 16. miejsce), w 2015 r. do 8,1 PLN (16. miejsce) na jednego mieszkańca. W całym badanym okresie nie odnotowano niższego wskaźnika wydatków inwestycyjnych na jednego mieszkańca w żadnym z województw. Najniższe wyniki to 11,5 PLN w województwie małopolskim i 12,1 PLN w opolskim, oba w 2015 r. Spadek poziomu finansowania inwestycji w kulturę w okresie 2011-2014 odnotowano także we wszystkich pozostałych województwach Polski wschodniej, a w 2015 r. właściwie w całej Polsce nastąpiło załamanie wydatków, na co wpływ miało z pewnością zakończenie projektów realizowanych w ramach poprzedniej perspektywy budżetowej Unii Europejskiej. Niemniej w województwie podlaskim spadek był największy w skali kraju. W okresie 2011-2014, czyli sprzed załamania, blisko 60-procentowy, podczas gdy w porównywanych regionach było to w granicach 9-20 proc. W 2015 r. podobne spadki, w granicach 56-63 proc. dotknęły województwa: podlaskie, lubelskie, świętokrzyskie i warmińsko-mazurskie. Pomimo znacznego obecnie obniżenia poziomu wydatków na inwestycje w całym kraju należy zauważyć, że utrzymanie trendu spadkowego może pogłębiać dysproporcje pomiędzy infrastrukturą kultury w Podlaskiem, gdzie już wcześniej inwestycje były mniejsze (mniej kosztowne) niż w pozostałych częściach kraju.

Poza wydatkami budżetowymi gmin istotnym elementem finansowania działań z zakresu kultury i edukacji kulturowej są również otrzymywane w drodze konkursów środki z Ministerstwa Kultury i Dziedzictwa Narodowego (MKiDN). Zestawienie kwot pozyskiwanych przez uprawnione do tego podmioty w poszczególnych regionach daje obraz kondycji finansowej sektora kultury w województwie podlaskim. W analizowanym okresie 2010-2014 ${ }^{6}$ każdego roku podmioty w województwie podlaskim były dofinansowywane przez MKiDN kwotami od 6 do 10 mln PLN. Stanowiło to ok. 4-6,4 proc. rocznych wydatków na kulturę z wszystkich budżetów gmin w województwie podlaskim. W tym czasie w skali całego kraju dofinansowania ministerstwa wynosiły pomiędzy $224 \mathrm{mln}$ a $367 \mathrm{mln}$ PLN, łącznie w okresie 2010-2014 pula wyniosła 1563 mln PLN. Z tej kwoty podmioty w województwie podlaskim otrzymały nieco ponad $39 \mathrm{mln}$ PLN, mniej pieniędzy uzyskały jedynie

6 W każdym omawianym $\mathrm{w}$ tym rozdziale przypadku korzystano z najbardziej aktualnych w momencie przygotowywania opracowania dostępnych danych. W tym wypadku były to statystyki za rok 2014. 
podmioty z województw opolskiego i lubuskiego. Podobnie jednak, jeśli chodzi o wysokość kwot wnioskowanych do ministerstwa, województwo podlaskie plasowało się każdego roku na pozycjach 13.-16., tak więc, przynajmniej na pierwszy rzut oka, podlaskie otrzymuje stosunkowo niewiele środków, ale również o niewiele wnioskuje (w badanym okresie były to kwoty pomiędzy 25 a $55 \mathrm{mln}$ PLN rocznie). Może się to wiązać z potencjałem ludnościowym województwa, gdyż w badanym okresie ostatnie pozycje w rankingach zajmowały, prócz podlaskiego, województwa opolskie i lubuskie, a więc regiony o najmniejszej liczbie mieszkańców, ale również, być może, ze stosunkowo niskim potencjałem kadr kultury, niepodejmujących prób zdobycia funduszy ze środków zewnętrznych lub czyniących to nieskutecznie ${ }^{7}$, bądź z problemami z wykazywaniem się niezbędnymi we wnioskach wkładami własnymi. Naturalnie, na podstawie badania danych zastanych niemożliwa jest odpowiedź na pytanie, dlaczego podmioty z województwa podlaskiego nie ubiegają się o więcej środków w ramach konkursów MKiDN. Można natomiast porównać otrzymywane kwoty z potencjałem województwa rozumianym jako odsetek ludności oraz odsetek produktu krajowego brutto (PKB) wytwarzany w regionie. Prezentuje to tabela 2. Województwo podlaskie otrzymując łącznie 2,5 proc. funduszy z konkursów MKiDN, uzyskało nieco słabszy wynik, niż wynikałoby to z udziału mieszkańców regionu w ogólnej liczbie ludności kraju (3,1 proc.), ale w podobnej sytuacji znalazła się większość województw. Jedynie dolnośląskie, małopolskie, mazowieckie i świętokrzyskie miały wyższy udział w dotacji niż w liczbie ludności kraju. Podobnie w wypadku drugiego wskaźnika - odsetka PKB - jedynie mniejsza część regionów osiągnęła wyższą pozycję w rankingu udziału w dotacji niż wytwarzanego produktu krajowego brutto.

W tej grupie znalazły się ponownie województwa: dolnośląskie, małopolskie, mazowieckie i świętokrzyskie, a ponadto warmińsko-mazurskie i podlaskie, a więc region ten znalazł się niejako w pozycji uprzywilejowanej. W porównaniu z innymi województwami Polski wschodniej w podlaskim różnica pomiędzy tymi trzema wskaźnikami (odsetki dotacji, ludności, PKB) jest najmniejsza ( 0,8 proc.), co sugeruje, że kwota otrzymanych dotacji dość dobrze odpowiada potencjałowi ludnościowemu i gospodarczemu regionu.

7 Wątek małej aktywności podmiotów w pozyskiwaniu środków zewnętrznych pojawił się m.in. w diagnozie współczesnej kultury w Suwałkach. Por. M. Białous, L. Kiszkiel, M. Skowrońska, Nowe kierunki, nowe drogowskazy. Współczesna kondycja kultury w Suwałkach, Urząd Miejski w Suwałkach, Suwałki 2015.. 
Tabela 2. Dofinansowanie z MKiDN a stan ludności i produkt krajowy brutto w województwach (w proc.)

\begin{tabular}{|c|c|c|c|c|c|c|c|}
\hline 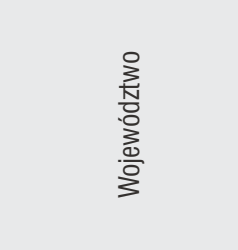 & 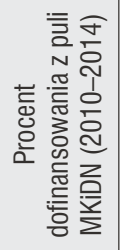 & 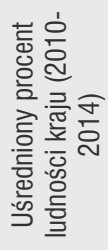 & 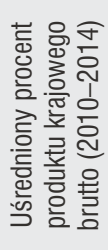 & 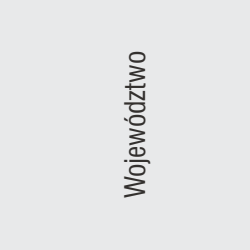 & 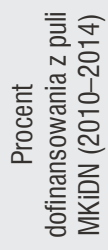 & 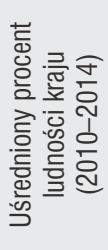 & 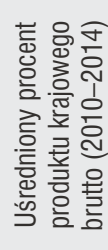 \\
\hline Dolnośląskie & 12,1 & 7,6 & 8,5 & Podkarpackie & 3,6 & 5,5 & 3,9 \\
\hline Kujawsko-pomorskie & 3,8 & 5,4 & 4,4 & Podlaskie & 2,5 & 3,1 & 2,3 \\
\hline Lubelskie & 3,4 & 5,6 & 3,9 & Pomorskie & 5,3 & 5,9 & 5,7 \\
\hline Lubuskie & 1,8 & 2,7 & 2,2 & Śląskie & 6,4 & 12,0 & 12,7 \\
\hline Łódzkie & 5,9 & 6,6 & 6,1 & Świętokrzyskie & 4,1 & 3,3 & 2,5 \\
\hline Małopolskie & 13,1 & 8,7 & 7,7 & Warmińsko-mazurskie & 3,5 & 3,8 & 2,7 \\
\hline Mazowieckie & 23,7 & 13,8 & 21,9 & Wielkopolskie & 6,3 & 9,0 & 9,5 \\
\hline Opolskie & 1,4 & 2,6 & 2,1 & Zachodniopomorskie & 3,0 & 4,5 & 3,7 \\
\hline
\end{tabular}

Źródło: opracowanie SocLab, soclab.org.pl, dostęp: 21.06.2017 na podstawie Bank Danych Lokalnych - Główny Urząd Statystyczny, https://bdl.stat.gov.pl, dostęp: 21.06.2017; Moja Polis, https://www.mojapolis.pl/, dostęp 21.06.2017.

W celu uzupełnienia przedstawionego wyżej obrazu warto jednak zwrócić uwagę na dwa dodatkowe wskaźniki. Pierwszym z nich jest skuteczność pozyskiwania środków, to znaczy odsetek z wnioskowanej puli, który ostatecznie trafił do beneficjentów, drugim, kwota otrzymanych funduszy w przeliczeniu na jednego mieszkańca.

Każdego roku tylko pewna część kwot wnioskowanych przez podmioty uczestniczące w konkursach ministerstwa trafia do beneficjentów. W skali państwa odsetek ten jest względnie stały i w latach 2010-2014 wahał się między 21,8 proc. a 24,9 proc. Rysunek 1 pokazuje skuteczność pozyskiwania środków przez podmioty z województwa podlaskiego na tym tle.

W latach 2011-2012 poziom skuteczności pozyskiwania środków w województwie podlaskim był nieco wyższy niż ogólnokrajowy. W roku 2012 do województwa podlaskiego trafiło aż 27,5 proc. wnioskowanej kwoty. Był to czwarty pod względem skuteczności wynik w Polsce, po województwach świętokrzyskim, mazowieckim i łódzkim. W latach 2013-2014 nastąpiło natomiast załamanie i w tym czasie podlaskie zajmowało odpowiednio 12. i 16. (ostatnie) miejsce pod względem skuteczności pozyskiwania środków. Tak złe wyniki można jednak przynajmniej częściowo wytłumaczyć łagodnym wzrostem liczby wniosków płynących z najmniejszych JST, gmin miejsko-wiejskich, a przede wszystkim wiejskich - hipotetycznie słabiej przygotowanych do pozyskiwania środków zewnętrznych - oraz kwotami, które uprawnione podmioty starały się uzyskać. Dla przykładu, podmioty z gmin wiejskich województwa 
podlaskiego wnioskowały w 2014 r. o kwotę 18,4 mln PLN, to jest o więcej niż w okresie 2011-2013 łącznie, ale ponad połowa $\mathrm{z}$ tej kwoty przypadła na jeden projekt (gm. Wyszki), który, nie otrzymawszy dofinansowania, znacznie obniżył wskaźnik skuteczności. Wyłączenie tego jednego projektu z analiz powoduje wzrost wskaźnika skuteczności wniosków o 2,8 proc, do poziomu 17,8 proc. Tak czy inaczej, wnioskom płynącym do ministerstwa z gmin wiejskich przyznano łącznie około 4,5 proc. kwoty, o którą aplikowały, co ujemnie odbiło się na statystykach dla całego województwa. Po 2012 r. nie zauważono natomiast wyraźnego wzmożenia aktywności podmiotów z gmin województwa podlaskiego w kierunku pozyskiwania środków z MKiDN (każdego roku wnioski składały podmioty z 46-50 gmin). Można to w jakimś sensie potraktować jako przykład wskazujący na potrzebę ciągłego podnoszenia kompetencji lokalnych kadr w zakresie wyszukiwania i zdobywania wniosków grantowych.

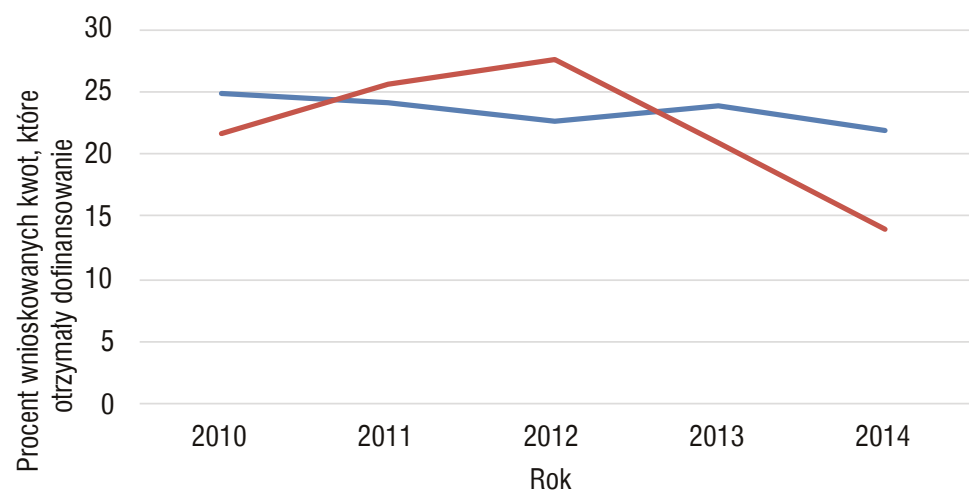

—— finansowania w kraju _— _ _ finansowania w województwie podlaskim

\section{Rysunek 1. Skuteczność pozyskiwania środków w konkursach MKiDN} w latach 2010-2014

Źródło: opracowanie SocLab, soclab.org.pl, dostęp: 21.06.2017 na podstawie Moja Polis, https://www.mojapolis. $\mathrm{pl} /$, dostęp 21.06.2017.

Tymczasem, jeśli chodzi o kwoty dofinansowań w przeliczeniu na jednego mieszkańca, podlaskie w badanym okresie stale utrzymywało się w połowie rankingu województw, zajmując pod tym względem miejsca 7.-10. W porównaniu z innymi województwami Polski wschodniej podlaskie zazwyczaj wyprzedzało pod tym względem województwa podkarpackie i lubelskie, ustępując województwom świętokrzyskiemu i warmińsko-mazurskiemu.

Warto przyjrzeć się również pozyskanym w poszczególnych województwach środkom z programów Unii Europejskiej. Kompleksowe porównanie wszystkich województw pod tym kątem byłoby dość trudne ze względu na fakt, że działania 
związane z kulturą mogą być finansowane z różnych programów, część z dofinansowanych projektów jest rozpisanych na kilka lat, w niektórych pojawiają się ponadto partnerzy $\mathrm{z}$ innych regionów lub państw. W związku z tym, dla uproszczenia, porównano dofinansowane projekty z zakresu ochrony dziedzictwa kulturowego i historycznego (przede wszystkim w ramach Regionalnych Programów Operacyjnych) według danych za 2014 r., nie wliczając w to korekt finansowych nakładanych przez organy kontrolujące. W przeliczeniu na jednego mieszkańca województwo podlaskie, podobnie jak w wypadku środków z MKiDN, otrzymywało stosunkowo niewielkie środki z funduszy europejskich, ponownie zamykając ranking razem z województwami lubuskim i opolskim. W porównaniu z województwami Polski wschodniej podlaskie zdecydowanie odstawało od lubelskiego, warmińsko-mazurskiego i podkarpackiego. Dokładne wyniki prezentuje tabela 3.

Tabela 3. Dofinansowanie z projektów UE w przeliczeniu na jednego mieszkańca według województw w 2014 r. (w PLN)

\begin{tabular}{|l|c|l|c|}
\hline \multicolumn{1}{|c|}{ Województwo } & $\begin{array}{c}\text { Projekty UE - ochrona } \\
\text { dziedzictwa kulturowego } \\
\text { i historycznego }\end{array}$ & Województwo & $\begin{array}{c}\text { Projekty UE - ochrona } \\
\text { dziedzictwa kulturowego } \\
\text { i historycznego }\end{array}$ \\
\hline Dolnośląskie & 161,23 & Podkarpackie & 67,28 \\
\hline Lubelskie & 117,91 & Zachodniopomorskie & 65,85 \\
\hline Mazowieckie & 100,84 & Łódzkie & 50,37 \\
\hline Kujawsko-pomorskie & 87,14 & Śląskie & 46,32 \\
\hline Małopolskie & 86,67 & Świętokrzyskie & 43,73 \\
\hline Wielkopolskie & 78,47 & Podlaskie & 41,45 \\
\hline Pomorskie & 71,20 & Lubuskie & 34,64 \\
\hline Warmińsko-mazurskie & 70,63 & Opolskie & 24,36 \\
\hline
\end{tabular}

Źródło: opracowanie SocLab, soclab.org.pl, dostęp: 21.06.2017 na podstawie Moja Polis, https://www.mojapolis. pl/, dostęp 21.06.2017.

Prócz wymienionych poniżej istnieje wiele innych źródeł pozyskiwania środków finansowych na działania z zakresu edukacji i animacji kultury, np. poprzez różnego rodzaju programy międzynarodowe lub fundacje. Trudno jest dokładnie oszacować i porównać skalę takiego dofinansowania oraz skuteczność podmiotów z różnych regionów w pozyskiwaniu środków. Po pierwsze, ze względu na mnogość źródeł, po drugie - na trudności definicyjne. Programy, które explicite finansują działania z zakresu edukacji kulturowej czy edukacji kulturalnej nie są bowiem jedynymi możliwościami dla podmiotów poszukujących dofinansowania. I tak na przykład, w ramach popularnego Funduszu Inicjatyw Obywatelskich (FIO), część projektów w ramach priorytetu Aktywni obywatele, a ściślej obszaru Rozwijanie edukacji 
obywatelskiej i kompetencji społecznych, jest faktycznie działaniami edukacji kulturowej. Z drugiej strony, z pewnością byłoby nieścisłością zaliczenie do tej kategorii wszystkich projektów finansowanych w ramach tego obszaru czy założenie, że działania z zakresu edukacji kulturowej nie znajdą się w żadnym z innych priorytetów. Rozróżnienie często jest arbitralne i wymagałoby drobiazgowej kwerendy lub dostępu do danych, które nie są publicznie udostępniane. Część wniosków ma również charakter ponadregionalny, dzięki czemu mieszkańcy województwa podlaskiego mogą się stać faktycznymi beneficjentami wniosków składanych przez podmioty z innych regionów. Wszelkie porównania utrudnia wreszcie fakt, że podmioty finansujące takie działania udostępniają w różnych zakresach dane dotyczące kwoty dofinansowań, siedziby wnioskodawców czy miejsca realizacji projektów. W związku z tym zdecydowano się na porównanie niektórych źródeł finansowania działań z zakresu edukacji kulturowej i kulturalnej (tabela 4), nie jest to jednak w żadnym razie lista wyczerpująca. Wzięto pod uwagę przede wszystkim podmioty o zasięgu ogólnopolskim; takie, które - we własnym pojęciu - dofinansowują działania z zakresu edukacji kulturowej, kulturalnej, animacji kultury itp. oraz udostępniają na stronach internetowych dane dotyczące beneficjentów umożliwiające dokonywanie porównań między regionami.

$\mathrm{W}$ przytoczonych $\mathrm{w}$ tabeli programach grantowych podmioty województwa podlaskiego otrzymywały od zera do ponad czterech procent z puli oferowanych środków. Osiągane wyniki najczęściej nie przekraczały więc poziomu wynikającego z potencjału ludnościowego i odsetka PKB województwa podlaskiego bądź przekraczały go w niewielkim stopniu. Ponieważ programy te dotyczyły dość różnych aspektów rzeczywistości, z jednej strony np. działań w kierunku podwyższania kompetencji uczniów w szkołach, a z drugiej skierowanej do wszystkich odbiorców edukacji filmowej, założyć można, że ogólny poziom finansowania działań z zakresu edukacji kulturowej jest w województwie dość niski - porównywalny z niektórymi województwami Polski wschodniej oraz najsłabiej zaludnionymi województwami opolskim i lubuskim. Jak jednak już wspomniano wcześniej, ustalenie przyczyn niedofinansowania ze źródeł zewnętrznych (np. brak wiedzy o takich źródłach, brak kompetencji w pozyskiwaniu środków, ograniczone możliwości wygospodarowywania wkładów własnych) wymyka się możliwościom analizy statystyk publicznych.

Pozostawiając w tym miejscu kwestię finansowania kultury, warto przyjrzeć się również syntetycznemu wskaźnikowi, tzw. indeksowi instytucji kultury GUS, pokazującemu łączną liczbę wszystkich instytucji kultury, na których spoczywa obowiązek sprawozdawczy wobec Głównego Urzędu Statystycznego ${ }^{8}$. Pod tym

8 Należą do nich: biblioteki i filie; domy i ośrodki kultury, kluby i świetlice; instytucje muzyczne: filharmonie i orkiestry symfoniczne oraz kameralne; teatry: teatr dramatyczny, teatr muzyczny rozrywkowy, 
względem województwo podlaskie, razem ze świętokrzyskim i lubuskim zamykają ranking (wyżej znajduje się natomiast słabiej zaludnione województwo opolskie). Jeśli jednak wziąć pod uwagę liczbę ludności w poszczególnych regionach, co pokazuje zrelatywizowany indeks instytucji kultury (w przeliczeniu na 1000 mieszkańców), województwo podlaskie przesuwa się znacznie wyżej, zajmując szóstą pozycję w kraju, po raz kolejny ze zbliżonym wynikiem do województwa lubelskiego. Innymi słowy, infrastruktura kulturalna $\mathrm{w}$ województwie podlaskim jest stosunkowo uboga, ale biorąc pod uwagę liczbę mieszkańców regionu, nie odbiega od przeciętnej.

Tabela 4. Wybrane źródła dofinansowania działań z zakresu edukacji kulturowej i podobnych

\begin{tabular}{|l|c|c|c|c|c|}
\hline \multicolumn{1}{|c|}{ Żródło } & \multirow{2}{*}{ Okres } & \multicolumn{2}{c|}{$\begin{array}{c}\text { Liczba dofinansowanych } \\
\text { wniosków }\end{array}$} & \multicolumn{2}{c|}{$\begin{array}{c}\text { Kwota dofinansowań } \\
\text { (w tys. PLN) }\end{array}$} \\
\cline { 4 - 6 } & & podlaskie & $\begin{array}{c}\text { pozostałe } \\
\text { województwa }\end{array}$ & podlaskie & $\begin{array}{c}\text { pozostałe } \\
\text { województwa }\end{array}$ \\
\hline $\begin{array}{l}\text { Fundusz Inicjatyw Obywatelskich (obszar } \\
\text { Rozwijanie edukacji obywatelskiej i kompetencji } \\
\text { społecznych) }\end{array}$ & $2014-2015$ & 4 & 210 & 177,3 & 10219,4 \\
\hline Fundacja BGK (konkurs „Na dobry początek”) & $2010-2016$ & 2 & 90 & 20 & 738,3 \\
\hline Fundacja Orange (Pracownie Orange) & $2012-2015$ & 1 & 76 & b.d. & b.d. \\
\hline Fundacja Orange (Akademia Orange) & $2013-2015$ & 2 & 90 & b.d. & b.d. \\
\hline $\begin{array}{l}\text { Fundacja BZ WBK („Bank Ambitnej Młodzieży”, } \\
\text { „Bank dziecięcych uśmiechów”) }\end{array}$ & 2016 & 2 & 96 & 19 & 436,9 \\
\hline $\begin{array}{l}\text { Polski Instytut Sztuki Filmowej („Edukacja } \\
\text { filmowa i kształcenie profesjonalne”, „Filmowe } \\
\text { inicjatywy lokalne”) }\end{array}$ & 2015 & 1 & 77 & 30 & 1040,5 \\
\hline $\begin{array}{l}\text { Narodowe Centrum Kultury („,Kultura } \\
\text { - interwencje”) }\end{array}$ & 2015 & 7 & 194 & 295 & 7720 \\
\hline $\begin{array}{l}\text { Mechanizm Finansowy Europejskiego Obszaru } \\
\text { Gospodarczego (Promowanie różnorodności } \\
\text { kulturowej i artystycznej w ramach } \\
\text { europejskiego dziedzictwa kulturowego) }\end{array}$ & $2012-2013$ & 4 & 49 & 1150 & 36 650 \\
\hline Fundacja Kronenberga & 2015 & 0 & 7 & 0 & 194,5 \\
\hline $\begin{array}{l}\text { Polsko-Amerykańska Fundacja Wolności } \\
\text { (,Równać szanse”) }\end{array}$ & $2014-2015$ & 2 & 52 & 76,5 & 1920 \\
\hline
\end{tabular}

Źródło: SocLab, soclab.org.pl, dostęp: 21.06.2017.

Kwestia infrastruktury kultury w centrach (stolicach) województw jako czynnika wpływającego na rozwój kapitału kulturowego i społecznego - temat pozostający w ścisłym związku z edukacją kulturową - była już przedmiotem dokładnych opracowań

operetka, teatr tańca, baletu, musicalu, teatr operowy, teatr lalkowy; obiekty działalności wystawienniczej: galerie i salony sztuki; kina stałe; muzea łącznie z oddziałami. Za: Moja Polis, op.cit. 
porównawczych. Warto przytoczyć badania B. Namyślak ${ }^{9}$. Autorka, zestawiając wskaźniki związane z liczbą instytucji, poziomem uczestnictwa oraz wydatkami na kulturę wykazała, że Białystok jest najsłabiej rozwiniętym pod względem kultury miastem wojewódzkim w Polsce (dla porównania Olsztyn - miejsce 9., Kielce - 13., Lublin - 14., Rzeszów - 15. ${ }^{10}$. Z metodologią B. Namyślak polemizował I. Sadowski ${ }^{11}$, który modyfikując nieco założenia, ustalił, że miastem o najsłabiej rozwiniętym sektorze kultury jest Bydgoszcz oraz na przedostatniej pozycji, ex aequo Białystok, Lublin i Szczecin. Ponownie wyżej uplasował się Olsztyn (7. miejsce), Kielce (8. miejsce), Rzeszów (10. miejsce). Oba teksty wskazywały więc na niski poziom rozwoju sektora kultury w stolicy województwa podlaskiego, chociaż według badania Sadowskiego przepaść pomiędzy Białymstokiem a resztą kraju nie jest aż tak widoczna, jak przedstawia to B. Namyślak ${ }^{12}$. Ponadto, w jego ujęciu, podobnie jak w części omawianych wyżej wskaźników GUS, zauważyć można podobną pozycję województw podlaskiego i lubelskiego.

Tabela 5. Indeks instytucji kultury GUS według województw

\begin{tabular}{|l|c|c|l|c|c|}
\hline Województwo & $\begin{array}{c}\text { Indeks } \\
\text { instytucji } \\
\text { kultury GUS } \\
(2014)\end{array}$ & $\begin{array}{c}\text { Indeks instytucji } \\
\text { kultury GUS } \\
\text { w przeliczeniu na } \\
1000 \text { mieszkańców } \\
(2014)\end{array}$ & Województwo & $\begin{array}{c}\text { Indeks } \\
\text { instytucji } \\
\text { kultury GUS } \\
(2014)\end{array}$ & $\begin{array}{c}\text { Indeks instytucji } \\
\text { kultury GUS } \\
\text { w przeliczeniu na } \\
1000 \text { mieszkańców } \\
(2014)\end{array}$ \\
\hline Mazowieckie & 1509 & 0,28 & Zachodniopomorskie & 793 & 0,46 \\
\hline Małopolskie & 1393 & 0,41 & Pomorskie & 753 & 0,33 \\
\hline Śląskie & 1339 & 0,29 & Kujawsko-pomorskie & 699 & 0,34 \\
\hline Wielkopolskie & 1183 & 0,34 & Opolskie & 573 & 0,57 \\
\hline Podkarpackie & 1123 & 0,53 & Warmińsko-mazurskie & 510 & 0,35 \\
\hline Dolnośląskie & 1040 & 0,36 & Podlaskie & 462 & 0,39 \\
\hline Lubelskie & 867 & 0,40 & Śiętokrzyskie & 462 & 0,37 \\
\hline Łódzkie & 855 & 0,34 & Lubuskie & 362 & 0,36 \\
\hline
\end{tabular}

Źródło: opracowanie własne na podstawie Moja Polis, https://www.mojapolis.pl/, dostęp 21.06.2017; SocLab, soclab.org.pl, dostęp: 21.06.2017.

9 B. Namyślak, Żróżnicowanie poziomu rozwoju sektora kultury w miastach wojewódzkich w Polsce, „Prace Geograficzne” 2013, z. 134, s. 101-120.

10 W rankingu uwzględniono 18 miast, wzięto pod uwagę „podwójne” stolice województw lubuskiego i kujawsko-pomorskiego.

11 I. Sadowski, Rozwój sektora kultury w Białymstoku na tle innych miast wojewódzkich w świetle danych urzędowych, http://ozkultura.pl/sites/default/files/stronaarchiwum/Rozw\%C3\%B3j\%20sektora\% 20kultury\%20 w\%20Bia\%C5\%82ymstoku.pdf, dostęp: 1.07.2016.

12 Miara rozwoju sektora kultury dla Białegostoku wynosi 0,055 ; dla zajmującego pozycję wyżej Szczecina 0,174; dla znajdującego się w połowie stawki Olsztyna 0,261 ; a dla zajmującego pierwsze miejsce Krakowa 0,731. B. Namyślak, op.cit., s. 115. 
Porównanie regionów na podstawie danych Głównego Urzędu Statystycznego warto uzupełnić jeszcze wskaźnikami dotyczącymi liczby imprez kulturalnych. Biorąc pod uwagę liczby bezwzględne, w $2015 \mathrm{r}$. w województwie podlaskim GUS odnotował ok. 8,1 tys. wydarzeń kulturalnych, co było 12 . wynikiem w Polsce. Zdecydowanie więcej wydarzeń zorganizowano na przykład w województwach podkarpackim (12,7 tys.) czy lubelskim (11,7 tys.). Podobnie jednak jak w wypadku indeksu instytucji kultury zrelatywizowanie wskaźnika poprzez uwzględnienie liczby ludności zamieszkującej poszczególne regiony sprawia, że podlaskie przesuwa się w rankingu do góry. Według wskaźnika liczby imprez na 1000 mieszkańców województwo podlaskie zajmuje czwarte miejsce $\mathrm{w}$ kraju, $\mathrm{z}$ wynikiem 6,86; wyraźnie lepszym od innych województw Polski wschodniej, dla których wskaźnik ten wyniósł pomiędzy 5,07 (warmińsko-mazurskie) i 5,97 (podkarpackie).

Tabela 6. Liczba imprez kulturalnych w województwach w 2015 r.

\begin{tabular}{|l|c|c|l|c|c|}
\hline \multicolumn{1}{|c|}{ Województwo } & $\begin{array}{c}\text { Liczba } \\
\text { imprez } \\
\text { ogółem }\end{array}$ & $\begin{array}{c}\text { Liczba imprez na } \\
1000 \text { mieszkańców }\end{array}$ & Województwo & $\begin{array}{c}\text { Liczba } \\
\text { imprez } \\
\text { ogółem }\end{array}$ & $\begin{array}{c}\text { Liczba imprez na } \\
1000 \text { mieszkańców }\end{array}$ \\
\hline Małopolskie & 24876 & 7,38 & Podkarpackie & 12710 & 5,97 \\
\hline Mazowieckie & 23353 & 4,37 & Lubelskie & 11724 & 5,48 \\
\hline Śląskie & 22891 & 5,01 & Kujawsko-pomorskie & 10394 & 4,98 \\
\hline Dolnośląskie & 16922 & 5,83 & Podlaskie & 8159 & 6,86 \\
\hline Wielkopolskie & 16317 & 4,70 & Opolskie & 8157 & 8,19 \\
\hline Łódzkie & 14663 & 5,88 & Warmińsko-mazurskie & 7302 & 5,07 \\
\hline Pomorskie & 13149 & 5,70 & Świętokrzyskie & 7237 & 5,76 \\
\hline Zachodniopomorskie & 12973 & 7,58 & Lubuskie & 6585 & 6,47 \\
\hline
\end{tabular}

Źródło: opracowanie SocLab, soclab.org.pl, dostęp: 21.06.2017 na podstawie Bank Danych Lokalnych - Główny Urząd Statystyczny, https://bdl.stat.gov.pl, dostęp: 21.06.2017.

Jak wspomniano wcześniej, województwo podlaskie nie jest jednolitym obszarem i można założyć, że życie kulturalne na jego terenie jest bardzo zróżnicowane. Tym samym istotne jest bliższe przyjrzenie się wskaźnikom dostępnym w statystyce publicznej na poziomie powiatów i gmin województwa podlaskiego. Także tym razem można rozpocząć od omówienia środków przeznaczanych przez poszczególne JST na wydatki związane z kulturą. W tym kontekście zwrócono uwagę przede wszystkim na dwa elementy:

- udział wydatków na kulturę we wszystkich wydatkach budżetowych JST,

- wydatki na kulturę (i osobno potraktowane wydatki inwestycyjne) w przeliczeniu na jednego mieszkańca. 
W 2015 r. średni udział wydatków na kulturę i ochronę dziedzictwa narodowego w ogólnych wydatkach budżetów gmin województwa podlaskiego wynosił 2,85 proc. Obliczając przeciętną udziału wydatków budżetowych w gminach poszczególnych powiatów odnotowano natomiast, że pod tym względem najlepsza sytuacja jest w powiatach białostockim, hajnowskim i mieście Suwałki, a najgorsza w powiatach zambrowskim, wysokomazowieckim i sokólskim. Ogólnie, dość wyraźnie poniżej średniej plasował się subregion łomżyński z wyłączeniem m. Łomża (powiaty zambrowski, wysokomazowiecki, łomżyński). Powiaty subregionu białostockiego pozostają stosunkowo bardziej zróżnicowane - obok znajdujących się wysoko powiatów białostockiego i monieckiego zdecydowanie niżej plasują się gminy powiatu sokólskiego. Dokładne wyniki przedstawia tabela 7.

Tabela 7. Średni udział wydatków budżetów gmin woj. podlaskiego na kulturę i ochronę dziedzictwa narodowego w 2015 r. (w proc.)

\begin{tabular}{|l|c|l|c|}
\hline $\begin{array}{c}\text { Jednostka samorządu } \\
\text { terytorialnego }\end{array}$ & $\begin{array}{c}\text { Średni udział wydatków } \\
\text { budżetów gmin na kulturę } \\
\text { i ochronę dziedzictwa } \\
\text { narodowego }\end{array}$ & $\begin{array}{c}\text { Jednostka samorządu } \\
\text { terytorialnego }\end{array}$ & $\begin{array}{c}\text { Średni udział wydatków } \\
\text { budżetów gmin na kulturę } \\
\text { i ochronę dziedzictwa } \\
\text { narodowego }\end{array}$ \\
\hline Powiat białostocki & 3,9 & Powiat bielski & 2,6 \\
\hline Powiat hajnowski & 3,9 & Powiat grajewski & 2,6 \\
\hline Miasto Suwałki & 3,7 & Powiat sejneński & 2,5 \\
\hline Powiat augustowski & 3,4 & Powiat suwalski & 2,4 \\
\hline Powiat moniecki & 3,1 & Powiat tomżyński & 2,4 \\
\hline Miasto Łomża & 2,9 & Powiat sokólski & 2,3 \\
\hline Powiat kolneński & 2,8 & Powiat wysokomazowiecki & 2,2 \\
\hline Powiat siemiatycki & 2,7 & Powiat zambrowski & 2,1 \\
\hline Miasto Białystok & 2,6 & \multicolumn{2}{|c}{} \\
\cline { 1 - 3 } & & &
\end{tabular}

Źródło: opracowanie SocLab, soclab.org.pl, dostęp: 21.06.2017 na podstawie Bank Danych Lokalnych - Główny Urząd Statystyczny, https://bdl.stat.gov.pl, dostęp: 21.06.2017.

W porównaniu z 2011 r., średni udział wydatków na kulturę i ochronę dziedzictwa narodowego w gminach obniżył się do 2015 r. o 1 proc. Trend spadkowy zauważono w 66 gminach, w 49 gminach odsetek wydatków budżetowych na kulturę wzrósł, a w trzech pozostał na niezmienionym poziomie. Spadków doświadczyło 60,2 proc. gmin wiejskich, 40,7 proc. gmin miejsko-wiejskich oraz 61,5 proc. gmin miejskich oraz miast na prawach powiatu. W wypadku miast spadki były zazwyczaj nieco łagodniejsze - 2,4 proc., przy 2,6 proc. dla gmin miejsko-wiejskich i 3 proc. dla gmin wiejskich - a kwoty samych budżetów wyższe, w związku z czym obniżenie wydatków na kulturę było z pewnością bardziej odczuwalne w najmniejszych gminach. 
Wskaźnikiem lepiej przemawiającym do wyobraźni niż odsetek wydatków budżetowych są kwoty wydawane na kulturę w poszczególnych JST w przeliczeniu na jednego mieszkańca. W 2015 r. średnia dla gmin województwa wynosiła 96,04 PLN, a mediana 86,92 PLN. Ze względu na kwoty wydatków w 2015 r. wszystkie gminy w województwie podzielono na cztery kategorie (kwartyle). Gminy pierwszego kwartyla wydawały na kulturę mniej niż 68,63 PLN na jednego mieszkańca; drugiego kwartyla w granicach 68,64-86,40 PLN; trzeciego kwartyla 86,41-110,40 PLN; czwartego kwartyla powyżej 110,40 PLN. Rysunek 2 pokazuje rozkład gmin poszczególnych kwartyli na mapie województwa.

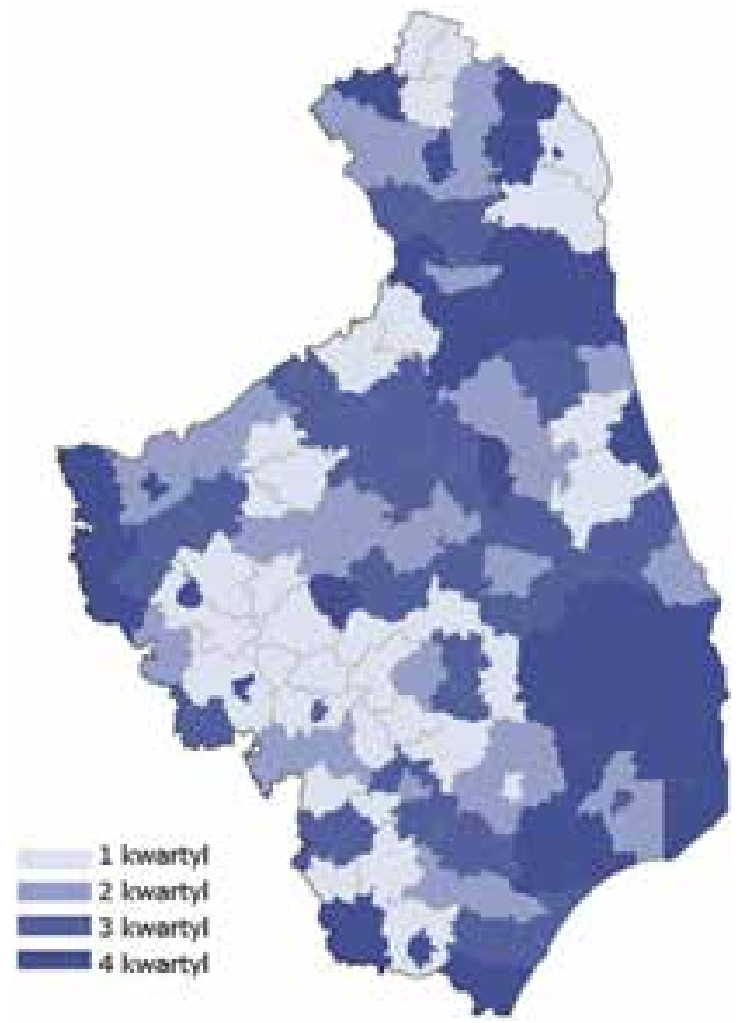

\section{Rysunek 2. Wydatki na kulturę w przeliczeniu na jednego mieszkańca w gminach województwa podlaskiego}

Źródło: opracowanie SocLab według raportu na temat stanu edukacji kulturowej woj. podlaskiego, soclab.org. pl, dostęp: 21.06.2017.

Tabela 8 pokazuje, że w pierwszym kwartylu, obejmującym gminy z najniższymi wydatkami na kulturę na głowę mieszkańca, znajdują się przede wszystkim gminy wiejskie. Patrząc całościowo, sytuacja jest jednak nieco mniej jednoznaczna, ponieważ 
jedna czwarta gmin wiejskich województwa podlaskiego należy do JST przeznaczających na kulturę najwięcej (powyżej 110,40 PLN na mieszkańca). Widoczna jest więc tutaj duża polaryzacja gmin wiejskich, które są liczne zarówno w pierwszym, jak i ostatnim kwartylu, nieco mniejsza ich liczba pojawia się natomiast w kwartylach środkowych. Odwrotna sytuacja jest w gminach miejsko-wiejskich, z których zdecydowana większość (70,3 proc.) znalazła się w drugim i trzecim kwartylu. Gminy miejskie, zgodnie z przewidywaniami, w większości znajdują się w trzecim i czwartym kwartylu (76,9 proc.), a więc należą do JST, które przeznaczają największe kwoty na kulturę w przeliczeniu na jednego mieszkańca. Wynika to m.in. z faktu, że w gminach miejskich (a przede wszystkim miastach na prawach powiatu) funkcjonuje więcej instytucji kultury, których organizatorami są samorządy, zobligowane do przekazywania instytucjom dotacji podmiotowych. Instytucje te wymagają również większych nakładów.

Tabela 8. Wydatki na kulturę na jednego mieszkańca w poszczególnych rodzajach gmin

\begin{tabular}{|l|c|c|c|c|c|c|}
\cline { 2 - 7 } \multicolumn{1}{c|}{} & \multicolumn{2}{c|}{ GW } & \multicolumn{2}{c|}{ GMW } & \multicolumn{2}{c|}{ GM / MP } \\
\cline { 2 - 7 } \multicolumn{1}{c|}{} & Liczba & Procent & Liczba & Procent & Liczba & Procent \\
\hline 1 kwartyl & 29 & 37,2 & 3 & 11,1 & 1 & 7,7 \\
\hline 2 kwartyl & 15 & 19,2 & 9 & 33,3 & 2 & 15,4 \\
\hline 3 kwartyl & 14 & 17,9 & 10 & 37 & 4 & 30,8 \\
\hline 4 kwartyl & 20 & 25,7 & 5 & 18,6 & 6 & 46,1 \\
\hline SUMA: & 78 & 100 & 27 & 100 & 13 & 100 \\
\hline
\end{tabular}

GW - gmina wiejska; GMW - gmina miejsko-wiejska; GM - gmina miejska; MP - miasto na prawach powiatu Źródło: opracowanie SocLABab na podstawie BDL GUS, soclab.org.pl, dostęp: 21.06.2017.

Tabela 9. Mediana wydatków na kulturę na jednego mieszkańca w poszczególnych rodzajach gmin

\begin{tabular}{|c|c|c|c|c|c|c|}
\hline \multirow{2}{*}{ Rodzaj gminy } & \multicolumn{5}{|c|}{$\begin{array}{l}\text { Mediana wydatków na kulturę bez wydatków inwestycyjnych } \\
\text { w przeliczeniu na jednego mieszkańca w roku (w PLN) }\end{array}$} & \multirow{2}{*}{$\begin{array}{c}\text { Procentowy wzrost } \\
\text { wydatków pomiędzy } \\
2011 \text { i } 2015 \text { r. }\end{array}$} \\
\hline & 2011 & 2012 & 2013 & 2014 & 2015 & \\
\hline Gmina wiejska (GW) & 65,56 & 71,95 & 77,50 & 79,57 & 79,59 & 21,4 \\
\hline Gmina miejsko-wiejska (GMW) & 76,19 & 76,68 & 82,85 & 88,65 & 89,21 & 17 \\
\hline Gmina miejska (GM) & 82,51 & 85,74 & 92,92 & 98,14 & 101,77 & 23,3 \\
\hline $\begin{array}{l}\text { Miasto na prawach powiatu } \\
\text { (MP) }\end{array}$ & 105,34 & 113,49 & 115,62 & 118,18 & 119,72 & 13,7 \\
\hline
\end{tabular}

Źródło: opracowanie SocLab, soclab.org.pl, dostęp: 21.06.2017 na podstawie Bank Danych Lokalnych - Główny Urząd Statystyczny, https://bdl.stat.gov.pl, dostęp: 21.06.2017.

Tabela 9 prezentuje medianę wydatków na kulturę w przeliczeniu na jednego mieszkańca w poszczególnych kategoriach gmin w latach 2011-2015. Dysproporcje 
pomiędzy nimi są dość wyraźne, sięgające od kilkunastu do kilkudziesięciu złotych, jednocześnie dynamika wzrostu podobna - nieznacznie szybsza w gminach wiejskich i miejskich, a wolniejsza w gminach miejsko-wiejskich oraz trzech największych miastach województwa podlaskiego. Należy również zwrócić uwagę, że dynamika wzrostu wyraźnie zahamowała we wszystkich typach gmin w 2015 r. Biorąc pod uwagę, że w tym samym czasie wystąpił wyraźny spadek wydatków JST na inwestycje w kulturze, zauważamy sytuację finansowego zastoju.

Porównując nakłady na inwestycje w latach 2011-2015 po raz kolejny widzimy dość wyraźne dysproporcje pomiędzy poszczególnymi kategoriami JST, co prezentuje tabela 10. Przeciętna gmina wiejska wydała na inwestycje w kulturę prawie dwukrotnie mniej niż przeciętna gmina miejska. W wypadku miast na prawach powiatu średnią znacznie podwyższyły wydatki Suwałk, budujących w tym okresie nową siedzibę Suwalskiego Ośrodka Kultury. Poziom wydatków inwestycyjnych w trzech największych miastach województwa był bardzo zróżnicowany. W Suwałkach wyniósł 41,5 mln PLN, w Białymstoku 18,7 mln PLN, w Łomży zaledwie 2,8 mln PLN. Ponadto, o ile w badanym okresie inwestowano w kulturę we wszystkich miastach na prawach powiatu, gminach miejsko-wiejskich oraz ośmiu z dziesięciu gmin miejskich, to w wypadku gmin wiejskich, aż $18 \mathrm{z}$ nich (21,8 proc.) nie przeznaczyło żadnych środków na inwestycje w kulturze. Według danych GUS z tej grupy aż osiem gmin $(44,4$ proc.) znajdowało się na obszarze powiatów wysokomazowieckiego i łomżyńskiego, a cztery gminy (22,2 proc.) na obszarze powiatów suwalskiego i sejneńskiego. Tym samym niedoinwestowanie tych obszarów może być jednym z czynników stojących za niskim poziomem aktywności kulturalnej, choć w badanym okresie nie zauważono korelacji pomiędzy środkami przeznaczanymi na inwestycje a liczbą organizowanych wydarzeń.

\section{Modele finansowania kultury przez jednostki samorządu terytorialnego}

Występuje istotne zróżnicowanie nakładów na inwestowanie w kulturę w zależności od rodzaju jednostki samorządu terytorialnego w analizowanym województwie. I tak, w latach 2011-2015 w gminach wiejskich średnio przeznaczano na ten cel 0,96 mln PLN, w gminach miejsko-wiejskich 1,18 mln PLN, w gminach miejskich - 1,79 mln PLN, zaś w miastach na prawach powiatu - 21 mln PLN. W przeliczeniu na jednego mieszkańca w latach 2011-2015 relatywnie najwięcej środków na ten cel przeznaczano w mniejszych społecznościach - gminach wiejskich oraz miejsko-wiejskich. W okresie 2011-2015 dla tych pierwszych mediana wydatków inwestycyjnych 
w przeliczeniu na jednego mieszkańca wyniosła 120,4 PLN; dla drugich 84,7 PLN. Tymczasem w miastach na prawach powiatu było to $63,2 \mathrm{PLN}$, a w gminach miejskich 17 PLN. Tabela 10 pokazuje natomiast wydatki dla gmin poszczególnych powiatów. Największe środki w przeliczeniu na mieszkańca przeznaczono na inwestycje w gminach powiatów sokólskiego i siemiatyckiego. Warto zwrócić uwagę na stosunkowo wysokie pozycje powiatów zambrowskiego i wysokomazowieckiego, które wypadają stosunkowo słabo z perspektywy większości innych, przytaczanych wskaźników. Być może środki przeznaczane $\mathrm{w}$ ostatnich latach na inwestycje wpłyną w tych wypadkach pozytywnie na wskaźniki dotyczące kultury w tych JST w przyszłości. Do tabeli włączone zostały również miasta na prawach powiatu, przede wszystkim, żeby pokazać skalę środków inwestycyjnych w Suwałkach, gdzie akurat powstawała nowa siedziba Suwalskiego Ośrodka Kultury ${ }^{13}$.

Tabela 10. Średnie wydatki na inwestycje na jednego mieszkańca w okresie 2011-2015 w gminach poszczególnych powiatów

\begin{tabular}{|l|c|l|c|}
\hline $\begin{array}{c}\text { Jednostka samorządu } \\
\text { terytorialnego }\end{array}$ & $\begin{array}{c}\text { Wydatki inwestycyjne } \\
\text { na jednego mieszkańca (PLN) }\end{array}$ & $\begin{array}{c}\text { Jednostka samorządu } \\
\text { terytorialnego }\end{array}$ & $\begin{array}{c}\text { Wydatki inwestycyjne } \\
\text { na jednego mieszkańca (PLN) }\end{array}$ \\
\hline Miasto Suwałki & 598,39 & Powiat suwalski & 123,97 \\
\hline Powiat sokólski & 224,56 & Powiat augustowski & 113,97 \\
\hline Powiat siemiatycki & 202,70 & Powiat hajnowski & 108,64 \\
\hline Powiat kolneński & 166,82 & Powiat grajewski & 78,54 \\
\hline Powiat zambrowski & 165,02 & Miasto Białystok & 63,21 \\
\hline Powiat wysokomazowiecki & 156,98 & Powiat tomżyński & 61,33 \\
\hline Powiat moniecki & 151,40 & Miasto Łomża & 44,58 \\
\hline Powiat bielski & 143,01 & Powiat sejneński & 5,67 \\
\hline Powiat białostocki & 133,74 & \multicolumn{2}{|r}{} \\
\cline { 1 - 3 } & & &
\end{tabular}

Źródło: opracowanie SocLab, soclab.org.pl, dostęp: 21.06.2017 na podstawie Bank Danych Lokalnych - Główny Urząd Statystyczny, https://bdl.stat.gov.pl, dostęp: 21.06.2017.

W pierwszej połowie drugiej dekady XXI w. wydatki na kulturę w przeliczeniu na jednego mieszkańca rosły we wszystkich typach gmin. Warto jednak zwrócić uwagę, według jakich wzorów zmieniał się w tym czasie poziom finansowania w poszczególnych gminach. W tym celu postanowiono wykorzystać zmodyfikowane modele, którymi posłużył się zespół B. Fatygi podczas diagnozy kondycji kultury w województwie warmińsko-mazurskim ${ }^{14}$. Biorąc pod uwagę zmiany kwot wydawanych na kulturę w przeliczeniu na jednego mieszkańca gminy, wyróżniono dziewięć

13 Na temat wpływu tej instytucji na lokalną kondycję kultury por. M. Białous i in., op.cit.

14 B. Fatyga i in., Kultura pod pochmurnym niebem. Dynamiczna diagnoza stanu kultury województwa warmińsko-mazurskiego, Olsztyn-Warszawa 2012. 
wzorów finansowania kultury, które można podzielić na trzy główne typy. Zostały one krótko scharakteryzowane w tabeli 11.

Tabela 11. Modele finansowania kultury w JST

\begin{tabular}{|l|l|l|}
\hline \multicolumn{1}{|c|}{ Typ finansowania } & Wzór finansowania & \multicolumn{1}{|c|}{ Opis } \\
\hline \multirow{3}{*}{ Stabilny } & Łagodny wzrost & Niewielki, ale systematyczny wzrost wydatków na kulturę rok do roku \\
\cline { 2 - 3 } & Stabilność & Stabilny poziom finansowania kultury bez wyraźnego trendu \\
\cline { 2 - 3 } & Łagodny spadek & Niewielki, ale systematyczny spadek wydatków na kulturę rok do roku \\
\hline \multirow{3}{*}{ Konwulsyjny } & Fala wypukła & $\begin{array}{l}\text { Wzrost wydatków na kulturę, po czym powrót do poprzedniego poziomu. } \\
\text { Może być fragmentem dłuższego cyklu }\end{array}$ \\
\cline { 2 - 3 } & Fala wklęsła & $\begin{array}{l}\text { Spadek wydatków na kulturę, po czym powrót do poprzedniego poziomu. } \\
\text { Może być fragmentem dłuższego cyklu }\end{array}$ \\
\cline { 2 - 3 } & Erupcja & $\begin{array}{l}\text { Gwałtowny wzrost wydatków na kulturę rok do roku i utrzymanie } \\
\text { na wyższym poziomie }\end{array}$ \\
\cline { 2 - 3 } & Załamanie & $\begin{array}{l}\text { Gwałtowny spadek wydatków na kulturę rok do roku i utrzymanie } \\
\text { na niższym poziomie }\end{array}$ \\
\cline { 2 - 3 } & Erupcja i załamanie & Gwałtowny wzrost, a następnie gwałtowny spadek wydatków na kulturę \\
\cline { 2 - 3 } & Konwulsje & $\begin{array}{l}\text { Duże różnice w poziomie wydatków na kulturę w poszczególnych latach, } \\
\text { bez wyraźnego trendu }\end{array}$ \\
\hline
\end{tabular}

Źródło: opracowanie SocLABab, soclab.org.pl, dostęp: 21.06.2017.

Wydaje się, że najbardziej pożądany z punktu widzenia rozwoju kultury i edukacji kulturowej jest wzór stabilnego, łagodnego wzrostu. Co prawda w JST, gdzie występował wzór erupcji, wydatki na kulturę w przeliczeniu na jednego mieszkańca wzrosły bardziej zdecydowanie (nawet kilkakrotnie), ale po pierwsze, w więcej niż połowie przypadków ( 55 proc.) po nagłych wzrostach nastąpiły równie gwałtowne spadki (wzór erupcji i załamania oraz konwulsji) i w dłuższej perspektywie odsetek ten może wzrastać, po drugie natomiast, można mieć wątpliwości, czy nagły wzrost wydatków na kulturę idzie w parze ze skutecznością działań. Nie stwierdzono bowiem istotnej korelacji pomiędzy erupcyjnym wzorem finansowania a wzrostem liczby wydarzeń kulturalnych oraz ich uczestników.

Typ stabilny finansowania zaobserwowano w 50 JST, a więc 42 proc. gmin województwa podlaskiego. Z tego w 31 przypadkach był to wzór łagodnego wzrostu, w skali regionu najczęstszy z obserwowanych wzorów. Tymczasem typ konwulsyjny odnotowano w wypadku 45 JST (38 proc. gmin), a więc jest on niemal równie powszechny jak typ stabilny. Aż w 21 wypadkach był to wzór konwulsji, a więc duże wahania nakładów na kulturę bez wyraźnego trendu. Powszechność typu konwulsyjnego może sugerować brak zrównoważonej i jasno określonej polityki kulturalnej na poziomie gmin. W 23 wypadkach (20 proc. gmin) rozpoznano typ falujący, w 12 przypadkach była to fala wypukła, w 11 - wklęsła. 
Trudno jest mówić o typowych modelach finansowania kultury w poszczególnych częściach województwa, choć typ stabilny nieco częściej występuje w gminach subregionu białostockiego ( $20 \mathrm{z} 33$ gmin), a konwulsyjny w subregionie południowym (17 z 26 gmin). W subregionach łomżyńskim i suwalskim częstość występowania tych typów rozkłada się mniej więcej po równo. Tabela 12 pokazuje natomiast typ finansowania w poszczególnych kategoriach gmin. Co prawda, pomiędzy rodzajem gminy a modelem finansowania nie występuje istotna statystycznie zależność, niemniej jednak warto zauważyć, że model stabilny, który z punktu widzenia polityki kulturalnej wydaje się najbardziej pożądany, jest najmniej charakterystyczny dla gmin wiejskich. Wzór ten pojawia się bowiem w 54 proc. gmin miejskich, 52 proc. gmin miejsko-wiejskich oraz 37 proc. gmin wiejskich, gdzie nieco częstszy okazał się wzór konwulsyjny ( 42 proc. gmin). Oczywiście, można powiązać stosunkowo częstszą niestabilność finansów gmin wiejskich z omówionymi, generalnie niższymi nakładami na kulturę w tych JST. Nawet stosunkowo niewielkie zmiany w finansowaniu kultury w najmniejszych, peryferyjnych gminach wiejskich mogą bowiem znacząco odbić się na kwocie wydatków na kulturę w przeliczeniu na mieszkańca. Niemniej jednak wydaje się, że JST dysponujące najmniejszymi środkami tym bardziej powinny dbać o stabilną politykę kulturalną i efektywne organizowanie życia kulturalnego w społeczności lokalnej.

Tabela 12. Modele finansowania kultury w poszczególnych kategoriach gmin

\begin{tabular}{|c|c|c|c|c|c|c|c|}
\hline \multirow{3}{*}{$\begin{array}{c}\text { Typ } \\
\text { finansowania }\end{array}$} & \multicolumn{7}{|c|}{ Kategoria gminy } \\
\hline & \multicolumn{2}{|c|}{$\begin{array}{l}\text { Gminy miejskie i miasta } \\
\text { na prawach powiatu }\end{array}$} & \multicolumn{2}{|c|}{ Gminy miejsko-wiejskie } & \multicolumn{2}{|c|}{ Gminy wiejskie } & \multirow[t]{2}{*}{ Suma } \\
\hline & Liczba & Procent & Liczba & Procent & Liczba & Procent & \\
\hline Falujący & 1 & 7,7 & 6 & 22,2 & 16 & 20,5 & 23 \\
\hline Konwulsyjny & 5 & 38,5 & 7 & 25,9 & 33 & 42,3 & 45 \\
\hline Stabilny & 7 & 53,8 & 14 & 51,9 & 29 & 37,2 & 50 \\
\hline Suma & 13 & 100 & 27 & 100 & 78 & 100 & 118 \\
\hline
\end{tabular}

Źródło: opracowanie własne na podstawie danych SocLABab, soclab.org.pl, dostęp: 21.06.2017.

W związku z powyższym warto, być może, poświęcić szczególną uwagę wydatkom na kulturę na mieszkańca w gminach wiejskich. Jak wynika z tabeli 13 różnice wydatków w gminach wiejskich w poszczególnych powiatach są wyraźne. Przy tym skrajne bieguny zestawienia wskazują też na dysproporcje geograficzne. Najwyżej notowane są powiaty z północnej (augustowski, sejneński), południowej (hajnowski) i białostockiej części województwa, tam znajduje się 14 z 20 gmin wiejskich (70 proc.), które plasują się w najwyższym kwartylu wydatków na kulturę na jednego mieszkańca. 
Tymczasem cztery ostatnie miejsca zajmują powiaty subregionu łomżyńskiego. Na tym obszarze tylko dwie gminy wiejskie (Miastkowo, Zbójna) znalazły się w najwyższym kwartylu wydatków na kulturę, znajduje się tam natomiast 15 z 29 (51,7 proc.) gmin wiejskich wydających na kulturę najmniej w przeliczeniu na jednego mieszkańca. Dwa ostatnie powiaty - wysokomazowiecki i zambrowski - mają wynik wyraźnie słabszy od pozostałych obszarów województwa.

Tabela 13. Mediana wydatków na kulturę na jednego mieszkańca w gminach wiejskich w poszczególnych powiatach

\begin{tabular}{|l|c|l|c|}
\hline \multicolumn{1}{|c|}{$\begin{array}{c}\text { Jednostka samorządu } \\
\text { terytorialnego }\end{array}$} & $\begin{array}{c}\text { Mediana GW 2015 } \\
\text { (w PLN) }\end{array}$ & \multicolumn{1}{|c|}{$\begin{array}{c}\text { Jednostka samorządu } \\
\text { terytorialnego }\end{array}$} & $\begin{array}{c}\text { Mediana GW 2015 } \\
\text { (w PLN) }\end{array}$ \\
\hline Powiat hajnowski & 125,06 & Powiat suwalski & 80,05 \\
\hline Powiat augustowski & 119,45 & Województwo podlaskie & 79,58 \\
\hline Powiat sejneński & 98,65 & Powiat siemiatycki & 78,25 \\
\hline Powiat białostocki & 87,88 & Powiat tomżyński & 68,17 \\
\hline Powiat sokólski & 85,37 & Powiat grajewski & 64,50 \\
\hline Powiat kolneński & 84,38 & Powiat wysokomazowiecki & 40,41 \\
\hline Powiat moniecki & 84,15 & Powiat zambrowski & 42,79 \\
\hline Powiat bielski & 83,43 & &
\end{tabular}

Źródło: Bank Danych Lokalnych - Główny Urząd Statystyczny, https://bdl.stat.gov.pl; SocLABab, soclab.org.pl, dostęp: 21.06.2017.

\section{Budżety instytucji kultury województwa podlaskiego}

Obecnie w województwie podlaskim funkcjonuje osiem wojewódzkich samorządowych instytucji kultury (we wrześniu 2016 r. doszła jeszcze jedna instytucja kultury o nazwie Podlaskie Muzeum Kultury Ludowej, wcześniej funkcjonujące jako Białostockie Muzeum Wsi w ramach Muzeum Podlaskiego w Białymstoku), dla których województwo podlaskie jest organizatorem i zgodnie z uchwałą budżetową zabezpiecza dotacje na działalność bieżącą. Łącznie z innymi dotacjami celowymi oraz dochodami własnymi instytucji dotacje podmiotowe umożliwiają realizację zadań statutowych poszczególnej jednostki. Poniżej porównano budżety wojewódzkich samorządowych instytucji kultury, opierając się na informacjach z zatwierdzonych przez sejmik województwa podlaskiego sprawozdań finansowych za rok 2014.

Największą dotację podmiotową z budżetu województwa w wysokości 13 mln PLN otrzymała Opera i Filharmonia Podlaska - Europejskie Centrum Sztuki w Białymstoku. Na drugim miejscu uplasowało się Muzeum Podlaskie z kwotą ponad 7 mln PLN. Trzecią instytucją była Książnica Podlaska im. Łukasza Górnickiego 
w Białymstoku, której dotacja podmiotowa wyniosła ponad 5 mln PLN. Następne to: Teatr Dramatyczny im. Aleksandra Węgierki - ponad $4 \mathrm{mln}$ PLN, Muzeum Rolnictwa im. ks. Krzysztofa Kluka w Ciechanowcu ponad 3 mln PLN, Wojewódzki Ośrodek Animacji Kultury w Białymstoku również ponad 3 mln PLN, natomiast najmniej środków otrzymały dwie instytucje kultury, a mianowicie Ośrodek „Pogranicze - sztuk, kultur, narodów" w Sejnach oraz Teatr Wierszalin w Supraślu. Ich dotacje podmiotowe opiewały kolejno na ponad 1,5 mln PLN i ponad 0,5 mln PLN. Warto wspomnieć, że obydwie instytucje, podobnie jak opera podlaska, są współfinansowane przez MKiDN. Łącznie na wszystkie dotacje podmiotowe w roku 2014 samorząd województwa podlaskiego przeznaczył około $38 \mathrm{mln}$ PLN. W porównaniu do roku 2013 z ponad $40 \mathrm{mln}$ PLN, był to spadek o ponad 5 proc. Jeśli chodzi o dotacje celowe, to w roku 2014 najwięcej środków z budżetu województwa otrzymała Książnica Podlaska w Białymstoku, której przekazano 7,5 mln PLN na zakup nieruchomości położonej przy ul. Marii Skłodowskiej-Curie 14A w Białymstoku z przeznaczeniem na nową siedzibę tej instytucji kultury. Drugie było Muzeum Podlaskie w Białymstoku, które otrzymało kwotę powyżej 1 mln PLN, w ramach której dokonano m.in. rewitalizacji wnętrz pałacowych w muzeum w Choroszczy, utworzono Ośrodek Edukacji Ekologicznej Muzeum Podlaskiego - Sokolarnia czy też wykonano remont dachów gontowych na czterech budynkach w Białostockim Muzeum Wsi (aktualnie w Podlaskim Muzeum Kultury Ludowej). Trzecią instytucją było Muzeum Rolnictwa im. ks. Krzysztofa Kluka w Ciechanowcu, które otrzymało ponad 500 tys. PLN z przeznaczeniem m.in. na zakup unikatowych ciągników do kolekcji muzeum oraz wymianę dachu zabytkowego budynku XIX-wiecznej stajni. WOAK w Białymstoku otrzymał 325 tys. PLN, w tym 250 tys. na wkład własny do projektu pn. „Dobudowa windy dla osób niepełnosprawnych przy kamienicy WOAK w Białymstoku" i 75 tys. z przeznaczeniem na adaptację podpiwniczenia Spodka C przy ul. Św. Rocha 14 w Białymstoku. Teatr Dramatycznym im. Aleksandra Węgierki otrzymał ponad 120 tys. PLN na wykonanie dokumentacji projektowo-kosztorysowej przebudowy jego wnętrz. Opera natomiast uzyskała 70 tys. PLN na wykonanie modelu akustycznego sali koncertowej. Teatr Wierszalin oraz Ośrodek Pogranicze w swoich sprawozdaniach za rok 2014 nie wykazały dotacji celowych z budżetu województwa.

Znacznym źródłem finansowania działań merytorycznych poszczególnej jednostki kultury są środki zewnętrzne, przede wszystkim z MKiDN, choć w wypadku niektórych instytucji kultury były to również dotacje z innych źródeł (RPO WP, WFOŚ). W 2014 r. najwięcej środków zewnętrznych pozyskało Muzeum Podlaskie, otrzymując ponad 630 tys. PLN, w tym: z MKiDN ponad 140 tys. PLN, m.in. na realizację takich projektów jak „Średniowieczne cmentarzysko w Czarnej Wielkiej, stan. 1 (badania 1951-1978) tom II” oraz „Wirtualna historia zabytku muzealnego 
XVI w. freski supraskie"; z Narodowego Funduszu Ochrony Środowiska i Gospodarki Wodnej Departamentu Funduszy Norweskich ponad 100 tys. PLN na Ośrodek Edukacji Ekologicznej Muzeum Podlaskiego - Sokolarnia; z Narodowego Instytutu Audiowizualnego ponad 300 tys. PLN na „Cyfrowe Muzeum I etap” oraz 65 tys. PLN z Miasta Białystok na remont elewacji Ratusza w Białymstoku. Na drugim miejscu znalazł się WOAK w Białymstoku, otrzymując prawie 0,5 mln PLN dotacji, w tym: z RPO WP na lata 2007-2013 prawie 400 tys. PLN na realizację zadania „Parada Województwa Podlaskiego”, z MKiDN 100 tys. PLN na realizację projektu „Dobudowa windy dla osób niepełnosprawnych przy kamienicy WOAK w Białymstoku" oraz ponad 10 tys. PLN z WFOŚ na realizację projektu „Uroda śmiecia - konkurs i warsztaty z upcyklingu”. Opera i Filharmonia Podlaska - Europejskie Centrum Sztuki w Białymstoku otrzymała 400 tys. PLN z MKiDN z przeznaczeniem na prace orkiestry w ramach cyklu koncertów symfonicznych z okazji jubileuszu 60-lecia. Muzeum Rolnictwa im. ks. Krzysztofa Kluka w Ciechanowcu otrzymało ponad 200 tys. PLN, w tym niemal połowę z MKiDN na takie zadania jak: „XXXIV Konkurs Gry na Instrumentach Pasterskich im. Kazimierza Uszyńskiego”, „Konserwacja silników stacjonarnych”, „Dokumentacja i monitoring w zarządzaniu obiektami budownictwa drewnianego w Muzeum Rolnictwa im. ks. Krzysztofa Kluka w Ciechanowcu oraz w Muzeum Ryfylke”. Pozostałe środki w wysokości 107 tys. PLN pochodziły z Mechanizmu Finansowego EOG na realizację projektu „Dokumentacja i monitoring w zarządzaniu obiektami budownictwa drewnianego w Muzeum Rolnictwa im. ks. Krzysztofa Kluka w Ciechanowcu oraz w Muzeum Ryfylke”. Z kolei Teatr Dramatyczny im. Aleksandra Węgierki z Ministerstwa Kultury i Dziedzictwa Narodowego otrzymał ponad 132 tys. PLN na realizację następujących zadań: „Szekspir” (50 tys. PLN) w ramach programu Edukacja, priorytetu Edukacja kulturalna; „Kierunek Chiny” w ramach priorytetu „Wydarzenia artystyczne - priorytet 5 - Promocja kultury polskiej za granicą” (50 tys. PLN), „Przypisy teatralne: Oskar Kolberg 2014” w ramach programu Kolberg 2014 - Promesa (32 tys. PLN). Teatr Wierszalin oraz Ośrodek Pogranicze w swoich sprawozdaniach za rok 2014 nie wykazały dotacji ze źródeł zewnętrznych.

Średnie wynagrodzenia w instytucjach kultury samorządu województwa podlaskiego w roku 2014 kształtowały się w przedziale od 2,7 tys. PLN do 4,3 tys. PLN. Spośród siedmiu wskazanych instytucji kultury w czterech zarobki przekraczają 4 tys. PLN i tak w Teatrze Dramatycznym jest to kwota 4,2 tys. PLN, w Ośrodku „Pogranicze - sztuk, kultur, narodów” w Sejnach 4,1 tys., w WOAK 4 tys. oraz we wspomnianej już wyżej OiFP - 4,3 tys. PLN. Zarobki przekraczające 3 tys. PLN wskazało Muzeum Rolnictwa im. ks. Krzysztofa Kluka w Ciechanowcu - 3,1 tys. oraz Książnica Podlaska im. Łukasza Górnickiego w Białymstoku - 3 tys. PLN. Najniższe średnie wynagrodzenie na poziomie 2,7 tys. PLN zanotowano w Muzeum Podlaskim. 
Wydatki w stosunku do przychodów w większości wojewódzkich samorządowych instytucji kultury są wyższe, a co za tym idzie, ich wynik finansowy jest ujemny. I tak największy deficyt budżetowy na poziomie - 470 tys. PLN zanotowało Muzeum Rolnictwa w Ciechanowcu przy przychodach 3,97 mln PLN i kosztach 4,44 mln PLN, druga była OiFP z wynikiem - 300 tys. PLN przy przychodach na poziomie $28,2 \mathrm{mln}$ PLN i kosztach 28,5 mln PLN. Następny jest Teatr Dramatyczny - 200 tys. PLN, mając przychody na poziomie 5,60 mln PLN i koszty 5,80 mln PLN, Książnica Podlaska - 180 tys. PLN przy przychodach na poziomie 9,22 mln PLN i kosztach 9,40 mln PLN oraz WOAK - 30 tys. PLN przy przychodach 4,44 mln i kosztach 4,47 mln PLN. Dodatni wynik zachowały trzy pozostałe instytucje, w tym: Ośrodek Pogranicze 16 tys. PLN (przychody - 2,27 mln PLN, koszty - 2,25 mln PLN), Muzeum Podlaskie 13 tys. PLN (przychody - 9,05 mln PLN, koszty - 9,04 mln PLN) i Teatr Wierszalin - 10 tys. PLN (przychody - 1,25 mln PLN, koszty - 1,24 mln PLN).

Z racji tego, że każda wojewódzka instytucja kultury ma swoją specyfikę i budżet adekwatny do swojej wielkości, miarodajnym wskaźnikiem skutecznego zarządzania finansami poszczególnej jednostki jest procent wypracowanych dochodów w stosunku do przychodów ogółem. I tak największe wypracowane dochody w stosunku do przychodów w roku 2014 na poziomie 27,6 proc. zanotowała OiFP, na drugim miejscu znalazł się Teatr Dramatyczny ze wskaźnikiem na poziomie 23,9 proc., następnie Muzeum Podlaskie - 19,4 proc., WOAK w Białymstoku - 17,3 proc., Muzeum w Ciechanowcu - 11,6 proc., Teatr Wierszalin zanotował natomiast wskaźnik na poziomie 10,7 proc. i Ośrodek „Pogranicze - sztuk, kultur, narodów” w Sejnach - 4,5 proc. Książnica Podlaska im. Łukasza Górnickiego w Białymstoku w swoim sprawozdaniu nie wykazała przychodów własnych, gdyż są one na bardzo niskim poziomie w stosunku do całkowitych przychodów jednostki.

$* * *$

Podsumowując, na tle innych regionów Polski województwo podlaskie prezentuje się jako stosunkowo słabo wyposażone w infrastrukturę kulturalną, z niewielką liczbą wydarzeń kulturalnych, niedofinansowane i niezbyt aktywnie poszukujące zewnętrznych środków finansowania kultury. Z pewnością częściowo tłumaczyć to można położeniem regionu w słabiej rozwiniętej gospodarczo Polsce wschodniej. W większości wypadków miejsce województwa podlaskiego w rankingach zbudowanych na wskaźnikach prostych pokrywa się z pozycją regionu według liczby mieszkańców. Nieprzypadkowo w tych samych rankingach, prócz podlaskiego, ostatnie miejsca zajmują często województwa lubuskie i opolskie.

W większości wypadków pozycja województwa podlaskiego na tle innych regionów prezentuje się nieco korzystniej, jeśli uwzględni się liczbę ludności zamieszkującej 
poszczególne części kraju. Wskaźniki relatywizowane pokazują województwo podlaskie jako region nieco poniżej średniej krajowej, ale pod wieloma względami nieodstający od innych województw Polski wschodniej. Stosunkowo najsłabiej wypadają wskaźniki związane z pozyskiwaniem środków finansowych oraz inwestycjami w kulturę - co może być niepokojące w kontekście potencjalnie rosnących w przyszłości dysproporcji pomiędzy Podlaskiem i innymi regionami - nieco lepiej, te związane z ofertą i poziomem uczestnictwa. Patrząc całościowo, przy uwzględnieniu liczby ludności, kondycja kultury województwa podlaskiego wydaje się najbardziej porównywalna do sytuacji w województwach lubelskim i świętokrzyskim. Znaczący jest natomiast poziom uczestnictwa mieszkańców w imprezach kulturalnych oraz ich współuczestnictwo w organizowaniu wielu z nich we współpracy z jednostkami samorządu terytorialnego lub jego instytucjami. Oznacza to w praktyce wdrażanie na poziomie regionalnym istotnych elementów współrządzenia publicznego (new public governance), co akcentuje się w literaturze przedmiotu jako najnowszy trend $\mathrm{w}$ prowadzeniu i realizowaniu polityki publicznej oraz polityk sektorowych ${ }^{15}$.

Jeśli chodzi o wojewódzkie samorządowe instytucje kultury, to każda z nich ma zapewnione finansowanie ze strony organizatora (samorządu województwa podlaskiego) w postaci dotacji podmiotowej, co umożliwia im stabilne utrzymanie i wykonywanie zadań statutowych. Dotacje celowe uzależnione są od realizacji konkretnych celów inwestycyjnych, jak również skutecznego pozyskiwania środków zewnętrznych. Warto wspomnieć, że samorząd województwa co roku zabezpiecza środki finansowe w ramach rezerwy budżetowej na pokrycie wkładów własnych do projektów realizowanych z funduszy unijnych czy też z MKiDN. Ułatwia to pozyskanie środków zewnętrznych, które stanowią znaczne wsparcie w finansowaniu działań merytorycznych i pozwalają na realizację nowych projektów kulturalnych. Średnie wynagrodzenie w wojewódzkich samorządowych instytucjach kultury jest bardzo zróżnicowane i kształtuje się w przedziale od 2,7 tys. do 4,3 tys. PLN. Można uznać, że taka rozpiętość wynagrodzenia wynika ze specyfiki zatrudnienia w danej jednostce, tzn. w niektórych instytucjach przeważają stanowiska techniczne (niżej opłacane), w innych merytoryczne (lepiej płatne). Strata finansowa w większości analizowanych instytucji kultury świadczy o tym, że pomimo otrzymania dotacji podmiotowej od organizatora i wypracowaniu dochodów własnych, poszczególne instytucje kultury nie są w stanie zbilansować wyniku finansowego swojej działalności, co może niepokoić. Wprawdzie wysokość deficytu nie przekracza amortyzacji, niemniej jednak taki stan rzeczy ograniczać może rozwój danej placówki, np. poprzez

15 Por. Polityka publiczna. Teoria. Jakość. Dobre praktyki, red. nauk. J. Osiński, I. Zawiślińska, Oficyna Wydawnicza SGH, Warszawa 2017. 
brak odpowiednich środków na odtworzenie zużytego wyposażenia. Dochody własne w wojewódzkich samorządowych jednostkach kultury kształtują się w przedziale od 4,5 proc. w mniejszych podmiotach do 26,7 proc. w tych największych, jakim jest bez wątpienia OiFP. Można uznać, że im większa instytucja kultury, tym większe możliwości generowania dochodów własnych.

\section{Bibliografia}

Białous M., Kiszkiel L., Skowrońska M., Nowe kierunki, nowe drogowskazy. Współczesna kondycja kultury w Suwałkach, Urząd Miejski w Suwałkach, Suwałki 2015.

Burszta W.J., Fatyga B., Kultura miejska w Polsce z perspektywy interdyscyplinarnych badań jakościowych, NCK, Warszawa 2010.

Fatyga B., Kultura pod pochmurnym niebem. Dynamiczna diagnoza stanu kultury województwa warmińsko-mazurskiego, Olsztyn-Warszawa 2012.

Finansowanie kultury i zarządzanie instytucjami kultury, J. Głowacki, J. Hausner, K. Jakóbik, K. Markiel, A. Mituś, M. Żabiński, praca zbiorowa, Uniwersytet Ekonomiczny w Krakowie, Małopolska Szkoła Administracji Publicznej, Kraków 2010.

Mielko C., Program działania Wojewódzkiego Ośrodka Animacji Kultury w Białymstoku na okres od 1 sierpnia 2014 r. do 31 lipca 2019 r. (zatacznik do uchwaly nr 247/3581/2014 Zarzadu Województwa Podlaskiego z dnia 29 lipca 2014).

Modzelewska M., Kukołowicz T., Finansowanie kultury przez samorzady. Plany, wykonania i realizacja wydatków na kulturę, NCK, Warszawa 2015.

Namyślak B., Żróżnicowanie poziomu rozwoju sektora kultury w miastach wojewódzkich w Polsce, „Prace Geograficzne” 2013, z. 134.

Polityka publiczna. Teoria. Jakość. Dobre praktyki, red. nauk. J. Osiński, I. Zawiślińska, Oficyna Wydawnicza SGH, Warszawa 2017.

Raport na temat stanu edukacji kulturowej województwa podlaskiego przygotowany przez Fundację SocLab (zlecenie Wojewódzkiego Ośrodka Animacji Kultury w Białymstoku w ramach projektu Podlaski Pomost Kultury zrealizowanego ze środków Narodowego Centrum Kultury), Białystok 2016.

Rozporządzenie Ministra Kultury i Sztuki z 6 stycznia 1999 r. w sprawie szczegółowych zasad wpisywania do wykazu obiektów stanowiących własność Skarbu Państwa lub jednostek samorząadu terytorialnego, w których prowadzona jest, jako podstawowa, działalność kulturalna lub które dla takiej działalności zostały wybudowane i nie mogą być przeznaczone do prowadzenia wyłącznie innej działalności podstawowej, oraz ustalenia ich wykazu, Dz. U. 1999, nr 21, poz. 185 z późn. zm. Zmiany Dz. U. 2006, nr 94, poz. 652.

Rozporządzenie Ministra Kultury i Dziedzictwa Narodowego z dnia 4 sierpnia 2010 r. zmieniające rozporządzenie w sprawie zakresu zadań objętych mecenatem państwa, szczegółowego trybu składania wniosków o udzielenie dotacji oraz trybu przekazywania i rozliczania udzielonych dotacji, Dz. U. 2010, nr 150, poz. 1005. 
Rozporządzenie Ministra Kultury i Dziedzictwa Narodowego z dnia 30 czerwca 2010 r. w sprawie szczegółowych warunków uzyskiwania dofinansowania realizacji zadań z zakresu kultury, trybu składania wniosków oraz przekazywania środków z Funduszu Promocji Kultury, Dz. U. 2010, nr 118, poz. 797.

Rozporządzenie Ministra Kultury i Dziedzictwa Narodowego z dnia 3 października 2012 r. w sprawie wynagradzania pracowników instytucji kultury, Dz. U. 2012, nr 0, poz. 1105.

Rozporządzenie Ministra Kultury i Dziedzictwa Narodowego z dnia 26 czerwca 2012 r. w sprawie zakresu zadań objętych mecenatem państwa w dziedzinie kultury, na które jednostki samorządu terytorialnego mogą otrzymywać dotacje, oraz sposobu i trybu przyznawania tych dotacji, Dz. U. 2012, nr 0, poz. 737.

Sadowski I., Rozwój sektora kultury w Białymstoku na tle innych miast wojewódzkich w świetle danych urzędowych, http://ozkultura.pl/sites/default/files/stronaarchiwum/Rozw\% C3\%B3j\%20sektora\%20kultury\%20 w\%20Bia\%C5\%82ymstoku.pdf

Ustawa z dnia 25 października 1991 r. o organizowaniu i prowadzeniu działalności kulturalnej, Dz. U. 2001, nr 13, poz. 123 z późn. zm.

Ustawa z 21 listopada 1996 r. o muzeach, Dz. U. 1997, nr 5, poz. 24 z późn. zm.

Ustawa z dnia 27 czerwca 1997 r. o bibliotekach, Dz. U. 1997, nr 85, poz. 539 z późn. zm.

Ustawa z dnia 5 czerwca 1998 r. o samorządzie województwa, Dz. U. 2001, nr 142, poz. 1590 z późn. zm.

Ustawa z dnia 5 czerwca 1998 r. o samorządzie powiatowym, Dz. U. 2001, nr 142, poz. 1592 z późn. zm.

Ustawa z dnia 24 lipca 1998 r. o zmianie niektórych ustaw określających kompetencje organów administracji publicznej - w związku z reformą ustrojową państwa, Dz. U. 1998, nr 106, poz. $668 \mathrm{z}$ późn. zm.

Ustawa z dnia 13 listopada 2003 r. o dochodach jednostek samorządu terytorialnego, Dz. U. 2008, nr 88, poz. 539 z późn. zm.

Wróblewski J., Raport z badań ex-post. Projekt SPEAK - Suwalski Program Edukacji i Animacji Kulturalnej, Suwałki 2015. 